\title{
Possibilities of the Ukrainian Online Platform OUM
}

\author{
Sergii Sharov, Vira Kolmakova, Tetiana Sharova, and Tetiana Kamyshova
}

\begin{abstract}
Introduction of information and communication technologies in the educational process has resulted in the emergence of innovative teaching techniques, new software and technologies. One of the effective means of distance learning is mass open online courses (MOOC). The purpose of the article is to analyze the possibilities provided by the Ukrainian online platform of the Open University of Maidan (OUM), and to compare it with other Ukrainian platforms (Prometheus, EdEra) according to certain criteria. The article reveals the main advantages and disadvantages of using MOOC both for self-development and in the educational process at higher education institutions. It has been found that MOOC provide lifelong learning and implement the principles of mass involvement and openness. They also offer free online courses and generate a certificate after their successful completion. We have identified some problematic issues which cover the imperfect system of practical tasks, the need to increase users' motivation, the language aspect, etc. The OUM online platform is primarily intended to provide civic education for community representatives and other users. We analyzed the thematic areas of the online platform and characterized them. The courses on this platform are mainly focused on the adult audience. They increase personal, communicative and civic efficiency, develop social entrepreneurship and understanding of the global content. Also, they ensure effective interaction with the authorities. During the content analysis we found that the OUM platform has specific features. In particular, it is the ability to form and graphically represent the individual educational trajectory; the platform contains exclusively Ukrainian-language content and provides an opportunity to be informed about the course progress via email. We dwelt on the possibilities of using MOOC by students, teachers and all those who are interested in self-study.
\end{abstract}

Index Terms-Education and development, higher education, information society, MOOC, OUM.

\section{INTRODUCTION}

Today we are witnessing a radical transformation in the content of higher education. This process is determined by the socio-economic changes, introduction of a competency-based approach into educational activities,

Manuscript received January 8, 2021; revised March 4, 2021.

Sergii Sharov is with the Department of Computer Sciences, Dmytro Motornyi Tavria State Agrotechnological University, Melitopol, Ukraine (e-mail: segsharov@gmail.com).

Vira Kolmakova is with the Department of Computer Science, Information and Communication Technologies, Pavlo Tychyna Uman State Pedagogical University, Uman, Ukraine (e-mail: kolmakova@udpu.edu.ua).

Tetiana Sharova was with the Department of Ukrainian and Foreign Literature, Bogdan Khmelnitsky Melitopol State Pedagogical University, Melitopol, Ukraine. Tetiana Sharova is now with the Department of Social Sciences and Humanities, Dmytro Motornyi Tavria State Agrotechnological University, Melitopol, Ukraine (e-mail: tanya_sharova@ukr.net).

Tetiana Kamyshova is with the Department of Germanic Philology, Bogdan Khmelnitsky Melitopol State Pedagogical University, Melitopol, Ukraine (e-mail: ktn61@i.ua). widespread integration of information and communication technologies (ICT). Under these conditions, the Ukrainian scientific and educational community is making great strides towards building an economically developed and democratic state, as well as towards training active and socially developed professionals. The same can be said about the initiatives which the state authorities are undertaking in order to give more autonomy to higher education institutions, to provide modernization of the higher education system and to follow the world and European standards [1].

Owing to the development of the Internet, mobile technologies, hardware and software, the concept of open education is now being successfully implemented. It means creating a single educational environment based on distance technologies to ensure lifelong learning. In order to achieve this aim, e-books on various subjects are widely used in secondary schools within the state program "The New Ukrainian School" [2]. In higher school, e-learning is carried out by means of various technologies, namely: distance learning systems [3], webinars, and various educational e-resources. Modern technologies allow creating cloud-oriented educational environment at universities [4]. This educational environment provides the use of media, learning materials, as well as creation of principally new forms of learning and teaching.

Today, the role of extracurricular training provided for future professionals is becoming more important. Also, there is an urgent need for continuous self-development and lifelong learning aimed at improving competitiveness and self-development. Therefore, we can observe increased attention to distance learning, especially to mass open online courses (MOOC). This issue is especially relevant due to the spread of COVID-19 and introduction of quarantine regulations in secondary and higher education institutions on the territory of Ukraine [5].

Mass open online courses can be seen as the next step in the development of distance learning systems [6]. The two systems have similar possibilities together with separate differences [7]. MOOC are dynamic, they are characterized by constant increase in the amount of online courses, variety of topics, and wide use in different countries [8]. The developers of mass open online courses create educational content and provide principles of education openness for those who are interested, regardless of their status and financial possibilities.

In higher education institutions of Ukraine MOOC are used to train future specialists both in the Humanities [9] and sciences [10]. In 2014, alongside with existing English-language online platforms such as Edx and Coursera [11], we could see the emergence of Ukrainian-language online courses such as Prometheus [12] and EdEra. The authors have published a number of research works on the 
possibilities and content of the above Ukrainian-language online platforms.

One of the well-known online platforms, which are actively developing on the territory of Ukraine, is the Open University of Maidan (OUM). Despite the fact that the OUM appeared in 2016, it is being actively filled with new courses and it demonstrates specific features which make it different from other similar platforms. The research study [13] presented the information on the possibility of the OUM use for IT-specialists training.

The specific content of the OUM courses, which are mostly aimed at providing the Ukrainian-language audience with civic education, will be useful for members of non-governmental organizations, communities, and small businesses. Unfortunately, there are no sufficient research studies which could describe educational possibilities and advantages of this online platform as it is relatively new.

\section{LITERATURE REVIEW}

\section{A. Advantages of MOOC}

Informatization of education involves introduction of ICT in the educational process, so the educational environment is filled with information technologies, digital gadgets, and various software products. The process of education informatization has led to the emergence of innovative teaching techniques and technological solutions for educational activities [14]; it has expanded the boundaries of communication and interaction based on a single educational environment.

One of the modern forms of e-learning is mass open online courses (MOOC) which are successfully used in course of university education. Also, they are used to improve teaching skills, for self-development, lifelong learning, etc. The analysis of the research works which are devoted to this phenomenon let us identify the following advantages of the MOOC [7], [15], [16]:

- Implementation of the ideas of humanism through educational practices, education internationalization, cooperation of educational institutions and organizations in different countries while developing online courses on various platforms;

- Ensuring the principles of mass, free, international and open education;

- Non-linear type of interaction between e-learning participants when knowledge is acquired through multimedia or in group communication;

- Open registration on the online platform or the course required;

- An opportunity to use MOOC for professional development through the improvement of the already acquired competencies or the development of new ones. This process takes place on the job at a user-friendly time;

- No restrictions (social, gender, age, etc.) to gain access to any courses;

- High flexibility in taking an online course which gives a possibility to study the information in an individual mode and to form the individual educational trajectory.

\section{B. Limitations of $M O O C$}

Like any other pedagogical system, mass open online courses have certain limitations in their use. First, they often lack practical tasks which are often imperfect. Second, it may be difficult to check the non-formalized tasks that cannot be reduced to tests [17]. Also, there is lack of face-to-face communication between the course participants and their developers/teachers [9]. In addition, some participants demonstrate a low level of motivation and self-control while taking an online course. Thus, the percentage of online courses that were fully completed is quite low (up to 10\%) [18]. Finally, the loss of interest to complete the course can be explained by the inconsistencies in the content of the course and its purpose, or by unclear or too difficult control questions, etc.

A problematic issue of online courses is the language aspect. For example, for the Ukrainian-speaking audience, taking English-language online courses on well-known foreign platforms is a rather complex process [19]. The emergence of Ukrainian-language online platforms has been a successful attempt to create a quality educational environment for Ukrainian-speaking audience. In this way, we managed to remove the language barrier, to increase the number of target audience, to promote the concept of open online education, and to create quality educational content. In addition, the interaction of Ukrainian MOOC with foreign partners provided an opportunity to integrate into the global educational space, to make online courses more interesting and of high quality.

\section{Methodology}

The given research is based on the analysis of the functional possibilities of the Ukrainian-language platforms according to the chosen criteria. The choice of MOOC for the comparative analysis was based on their popularity among the Ukrainians and on our own practical experience. The realization of this task meant the performance of the following stages:

- Registration on the three platforms (EdEra, Prometheus, OUM) which were chosen for the further analysis;

- Acquaintance with the thematic areas of online courses on each of the online platforms;

- Registration for courses in various thematic areas, their full completion and obtaining a certificate. The authors completed successfully more than 30 online courses on each platform (EdEra - 39, OUM - 48, Prometheus - 112 courses), and they got certificates;

- Formation of a list of criteria that can be used for the comparative analysis of the Ukrainian-language online platforms.

The method of the content-analysis was used to evaluate the content of online courses on various topics, the ways to control educational achievements, the means to form the individual educational trajectory within the OUM platform. Currently, the platform has 70 online courses, of which 48 courses $(68.6 \%)$ were completed by the authors. 


\section{RESULTS}

Today, the most popular Ukrainian MOOC platforms are the Prometeus [14], Edera, and OUM where online courses on various topics are actively developed and a possibility for self-improvement is provided for free.

Common and distinctive features of these platforms are presented in Table I.

TABLE I: CHARACTERISTICS OF THE PROMETEUS, EDERA, OUM PLATFORMS

\begin{tabular}{|l|c|c|c|}
\hline Criterion & Prometeus & Edera & OUM \\
\hline $\begin{array}{l}\text { Registration through Google or } \\
\text { Facebook accounts }\end{array}$ & + & - & + \\
\hline $\begin{array}{l}\text { Availability of the content in } \\
\text { Ukrainian }\end{array}$ & + & + & + \\
\hline Availability of paid content & + & + & - \\
\hline Free training courses & + & + & + \\
\hline Unlimited number of students & + & + & + \\
\hline Automatic course search & + & - & + \\
\hline $\begin{array}{l}\text { The material is combined with } \\
\text { control tests }\end{array}$ & + & + & + \\
\hline $\begin{array}{l}\text { The certificate has a date of } \\
\text { issue }\end{array}$ & + & + & + \\
\hline The certificate has a number & - & - & + \\
\hline $\begin{array}{l}\text { Display of courses in the form } \\
\text { of a rubricator }\end{array}$ & + & - & + \\
\hline $\begin{array}{l}\text { Graphical representation of the } \\
\text { course progress }\end{array}$ & + & + & $+/-$ \\
\hline $\begin{array}{l}\text { The certificate is generated } \\
\text { immediately after the course } \\
\text { completion }\end{array}$ & + & + & + \\
\hline $\begin{array}{l}\text { Certificates are downloaded to } \\
\text { the personal account }\end{array}$ & + & + & + \\
\hline $\begin{array}{l}\text { Informing about new courses } \\
\text { through a digest }\end{array}$ & + & + & + \\
\hline $\begin{array}{l}\text { Informing about the course } \\
\text { progress via email }\end{array}$ & + & + & + \\
\hline $\begin{array}{l}\text { The number of hours is } \\
\text { specified on the certificate }\end{array}$ & + & + & + \\
\hline
\end{tabular}

As we can see from Table I, the common characteristics for all the above MOOC are the availability of the content in Ukrainian, free online courses, unlimited number of students, automatic certificate generation in the users' personal accounts, certificates with the date of issue, and users' informing about new courses.

In our research, we will focus on the description of the structure and main educational possibilities of the OUM platform which was created in 2016. Its main goal is the development of civil society in Ukraine. This resource differs from other online platforms in such features: it forms the students' educational trajectory in an original way, it generates a certificate immediately after the successful completion of the course, and it informs participants about the course progress via email. It is worth noting that the age and number of students are not limited on the OUM online platform. They can be children, students, and the elderly who are interested in lifelong learning.

The advantage of the OUM online platform is the availability of a unique number on the certificate reflecting the number of hours spent on watching the video content; it is a kind of identity indicating that the course belongs to the platform. The users who take the online course always have an opportunity to view its content, get acquainted with the teachers, as well as to navigate among the number of tests and video lectures. This information allows users to manage their time properly and to complete the course successfully.

After registering on the resource, the users enter their own account that displays a list of selected courses and the personal activity. An original way to display the individual educational trajectory is a course diagram which provides the users with an opportunity to view all the courses on the site, as well as to monitor their own activity in different areas.

All the courses on the OUM online platform are divided into six areas (Fig. 1):

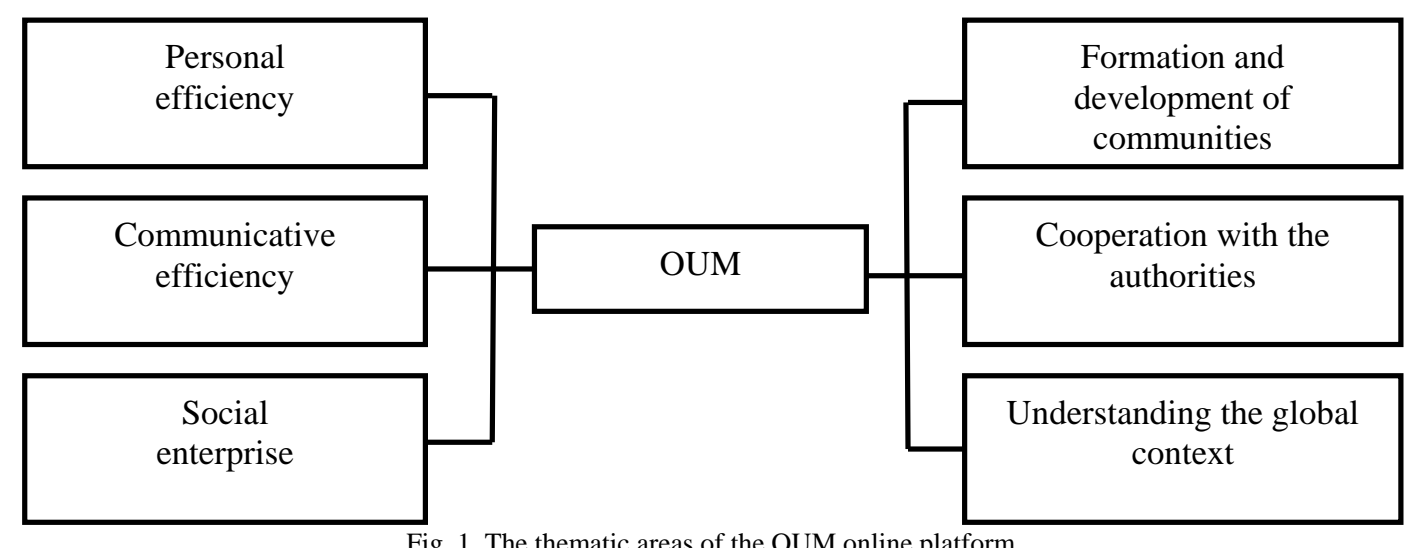

Fig. 1. The thematic areas of the OUM online platform.

Let us characterize briefly each of the areas.

The area of "Personal efficiency" encourages the user to achieve personal goals, to work for self-improvement and self-realization. In order to do this, the courses in this area provide information about the types of thinking (strategic, critical, and creative) and explain the importance of lifelong learning. During video lectures the developers help users to set their goals correctly, give recommendations as for their implementation, development of life plans, solution of problematic issues, etc.
The area of "Communicative efficiency" deals with the interaction of people in society. Here, users can learn about some general principles of tolerant attitude to people, politeness, mutual understanding and assistance, ethical norms of behavior in society. In this thematic area the developers explain how to manage society, what methods and techniques can be used to build a good reputation and gain respect among others. Much attention is paid to issues of media literacy. General concepts of true and fake information, media, etc. are explained. It should be noted that this area is 
one of the most popular because media literacy helps to quickly exchange important information, distinguish it from false information, and to be able to search for it in various sources.

The area of "Social enterprise" helps you to learn about the changes taking place in the economy. When users choose this area they have an opportunity to understand the market economy, its structure and development trends. Also, they learn how to understand management. In the sub-areas on finance, the course developers report on the ways how to fundraise for the required activity; they teach how to calculate costs correctly, and so on. The courses in this area contain practical tasks where calculations and work with numbers are done. In addition to dealing with the formulas and rules of economic calculations, users can learn about the content and rules of providing information in order to get necessary funding, or register a project, etc.

In the area of "Formation and development of communities", developers draw users' attention to the social order and development. This area is one of the most detailed, as it covers a large number of problematic issues. It addresses issues of teamwork and leadership, community organization, self-government, use of shared public resources, economic development of the community, social communications (social marketing, social capital), etc. Also, in this section a large number of courses are devoted to parenting. Developers are concerned about this issue, because at the moment in Ukraine there are a large number of fraudsters who take away housing from people. Most of these people have children, so the developers are trying to explain the problem and to protect people from mistakes. During the video lectures the issues of family budget organization, loan application, etc. are discussed. This reduces the risk of falling into the hands of fraudsters.

The area of "Cooperation with the authorities" deals with legal and law support of the population. This area explains the key issues of advocacy, lobbying, harassment, discrimination, and so on. This information will help users in case they get into similar situations, so they will know who to ask for help. This area also provides information on the human rights in society, human rights to healthcare, fight against corruption, legal system in Europe, etc. In course of training, users have an opportunity to find answers to the questions related to cooperation with the authorities, and if necessary, they will be able to defend their rights in compliance with applicable law.

The direction of "Understanding the global context" will help users to better interact with society both in Ukraine and abroad, to understand that the country and society are in constant development and interaction. The courses in this area provide acquaintance with cultures of different countries; they tell about their development, traditions, and heritage. Also, this area gives general understanding of the human rights provided by the Constitution of Ukraine. In such a way, people can understand the principles of sustainable development. The developers are trying to explain the principles which help to create public structures, to manage them, and to cooperate with other states.

If a user has chosen a certain area and wants to see the list of online courses only by this direction, then you need to click on the moving window "Courses", and then on the button "Course Rubricator". Here you can view the courses under different headings, and choose the ones you need for further study.

It is necessary to say that on the OUM platform some courses are repeated in different areas. What is more, all the courses are interconnected. Thus, in the first area there are four sub-areas containing 31 online courses. The second area contains 16 online courses. There are 35 online courses in the third area of "Social Enterprise". The area of "Understanding the global context" contains five sub-areas with total of 66 online courses. The fifth area of "Cooperation with the authorities" gives users an opportunity to take 38 courses, and the area of "Formation and development of communities" contains 56 online courses in six sub-areas (Table II).

TABLE II: THE QUANTITATIVE ANALYSIS OF ONLINE COURSES ON THE

\begin{tabular}{|l|c|c|}
\hline OUM PLATFORM & $\begin{array}{c}\text { Number of } \\
\text { sub-areas }\end{array}$ & $\begin{array}{c}\text { Number of } \\
\text { courses }\end{array}$ \\
\hline Personal efficiency & 4 & 31 \\
\hline Communicative efficiency & 3 & 16 \\
\hline Social enterprise & 5 & 35 \\
\hline $\begin{array}{l}\text { Formation and development of } \\
\text { communities }\end{array}$ & 6 & 56 \\
\hline Cooperation with the authorities & 4 & 38 \\
\hline Understanding the global context & 5 & 66 \\
\hline
\end{tabular}

At the same time, the developer's website states that the total number of courses is only 71 courses as of December 2020. Accordingly, we observe repeated online courses in the sub-areas. The latter is explained by the specifics of getting civic competencies.

We emphasize the fact that on the OUM platform all areas are interconnected and they cannot exist separately. If you choose courses from different areas, you can follow in the personal account how the individual training web is distributed. Each successfully completed course testifies to the improvement of user competencies. For example, the course "School of the Conscious Citizen" is designed to carefully familiarize oneself with the basic characteristics of the citizen. However, in order to master the program and obtain a certificate, you must take another 10 courses: "Introduction to critical thinking", "Constitution of Ukraine: the citizen's ABC", "Integral dynamics", "Public control", "Effective management of common property through a condominium association (OSBB)", "Who is who? Psychological age of people and communities", "Creative activism", etc. These courses can be taken in any order.

The above features are considered to be the advantages of this platform. Also, they make it different from other Ukrainian platforms.

On the OUM platform, the course navigation is quite convenient, so users can find some popular courses or those ones for which registration has been announced, but they are still at the stage of development. Such courses allow you to systematically move towards self-education, gradually performing the current tasks as they are loaded into the system. The automatic course search allows you to highlight all the courses on the screen that the user can subscribe to.

You can greatly simplify the search for the desired online 
course by using the tag field. When you click on a specific tag, the system immediately redirects a user to the courses with a similar tag. As a result, you can quickly add the required courses to your own account, and then you can take the course and get a certificate.

Before registering for a specific course, you can learn more about its purpose and content using the link "Details". Each course offers a general description, purpose and aims, information about the developers. Below there is a list of similar courses that you can take later. The name of each course is presented in the form of a hyperlink, which facilitates users' search and saves their time. Also, there are comments and ratings of the users who have already completed this course. That is, users are given an opportunity to express their own impressions of the course. Through this feedback, developers can understand what shortcomings need to be worked on, what has to be corrected, which tasks are difficult, which ones need to be improved or replaced, and so on.

The user can immediately subscribe to the selected course using the "Subscribe to the course" button or add it to favourites. By adding a certain course to the user account, you can view information about the duration of the course, the number of video lectures and blocks. You can get acquainted with the tasks and purpose of the course. The information on the number of users who have completed the course and received a certificate is also useful.

The popularity of certain courses among users can be explained by the following criteria:

- Relevance of the issues reflected in the courses, the possibility of their presentation with the help of video lectures;

- The possibility to complete test tasks to achieve learning outcomes and to obtain a certificate;

- Interesting presentation of the lecturer's opinion;

- Partnership between the platform developers and online courses developers;

- Number of subcategories in the rubricator according to the chosen course;

- Educational content which is displayed as an online course.

While taking a course you can communicate with other students and teachers. Sometimes such communication is needed to perform practical tasks and load them into the system. However, most of the courses are set up to watch videos and listen to lectures followed by test assignments.

After the successful completion of the course a certificate will be generated in the automatic mode on the official form of the OUM platform. The certificate has a unique number; it contains the course name, the name of the lecturer or organization that is the developer of the course. An interesting feature of the certificate is that it specifies the number of hours spent by the student to watch video lectures, and it shows the real time required to study this course.

After taking a certain number of courses on the OUM online platform, you can follow your own educational trajectory. It is worth noting that educational dynamics is increasing towards the area where the largest number of online courses has been taken. Accordingly, the electronic web of a particular user (his/her individual educational trajectory) can change. For example, Fig. 2 shows the state of the individual educational trajectory of a novice user (a) and an experienced user (b) when they have completed a certain number of courses. In the first case, the user took only 6 courses $(8.6 \%)$, in the other -48 courses, which is $68.6 \%$ of the total number of courses on the platform:

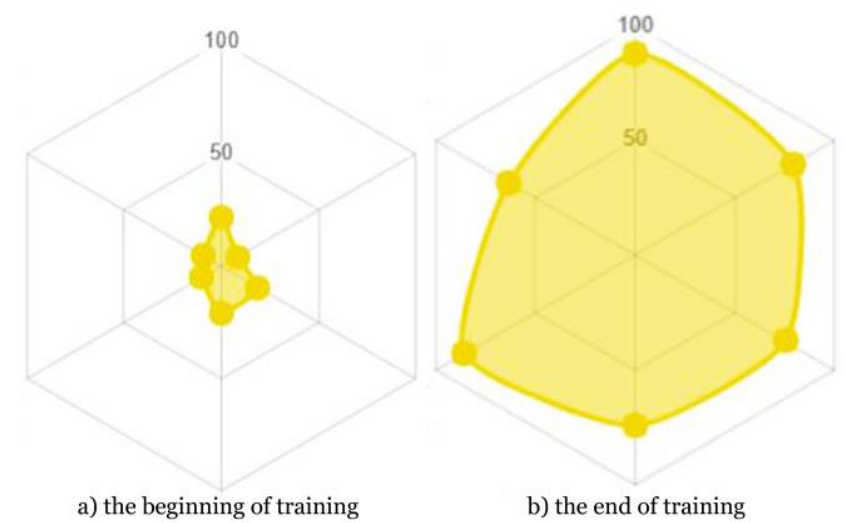

Fig. 2. The user's individual educational trajectory at the beginning and at the end of training.

Of course, users can continue to take online courses according to their educational needs. In this case, the educational web will increase.

In our opinion, the weaknesses of the OUM platform are as follows:

- After adding a course to the personal account you cannot unsubscribe from it;

- Also, in our opinion, it is wrong from the developers' point of view to deprive the users of a chance to complete a course in case they fail three attempts to pass a test. There are some positive shifts in this direction, though. After failing three attempts, you can write to the developers and get additional attempts.

- Sometimes, after adding courses of a certain area to the personal account, it is possible to take them only in a certain sequence. And if the previous course has not been taken, the user is not able to take other courses.

Despite these shortcomings, which are also features of the platform, each user has an opportunity to build his/her training web and develop all the necessary competencies.

\section{DISCUSSION}

In our opinion, using online courses on the OUM platform and other MOOC is appropriate in several cases:

1) Anyone can use the OUM online platform in course of self-education, as the courses offer high-quality Ukrainian-language content. They allow users to form civic and social competencies. The users will be able to learn a lot of new things; they will be aware of certain legislative documents, the rules of conduct in communities and so on. However, it should be understood that the thematic areas of the courses are not related to school subjects. Most likely, these courses are important for adults, because they deal with communication, entrepreneurship, global context, economics, business and government.

2) From the students' point of view, the optimal form of 
using MOOC in an educational institution is a combination of distance learning with the work in the classroom [20]. In this way students master the basic educational content in class, whereas some topics are studied online.

3) MOOC is a very useful electronic resource for teachers and lecturers. They contain a variety of educational material; they allow you to be aware of current achievements, and they can help to create your own training courses.

One of the problematic issues which require solution is the motivation decline while taking an online course. The reasons might be different: low-quality content, uninteresting topics of the online course, problems with the course display image on a mobile device, unstable Internet. In order to boost motivation for taking MOOC, we can offer several options: with the help of students; with the help of a teacher; with the platform specific features, etc.

As for users/students, their motivation boosters are professional identity, excitement of learning something new, future profits [21], development of the latest competencies and personal qualities [8]. The OUM online platform is quite interesting from the perspective of personal achievements representation while taking a course. In comparison with other Ukrainian-language platforms, such as Prometheus and EdEra, it provides users with educational web which expands after the course has been completed. It may increase interest to complete the current online course and to register for new courses.

In case of mixed learning, it is possible to provide motivation with the help of a teacher [9]. In this case, a teacher acts as a mentor who helps to find the proper online course. The research [22] proves the efficiency of teachers and students' common activity while taking an online course. Besides, the research [23] proves usefulness of certain attitudes and instructions that increase the self-regulation level and that are given to users while they are taking an online course.

The efficient mechanism for the motivation increase is recognizing the results of non-formal learning within the boundaries of the higher education institution autonomy. In this case, we should motivate students to obtain certificates proving the successful completion of courses by giving them additional points/grades in certain subjects where similar topics are studied.

It is also possible to increase the effect of MOOC in course of learning with the help of group work. Usually, taking an online course involves an objectivist-individual approach [18] which means students' individual work during their self-study work. The research [24] states that users lose interest to online learning without having a possibility to communicate with other users who are also taking this course. Creating an online community which is using the same online course to master a certain learning topic or a subject will provide mutual activity and communication between the participants of the educational process [7]. The above tendency is also characteristic of teachers [25] who can get better prepared for using distance learning technologies in the educational process with the help of group work.

\section{CONCLUSION}

Thus, distance learning is now actively realized in higher education and in lifelong learning. MOOC, which is one of the effective means of implementing distance learning, offers users a variety of courses, including free ones. The pedagogical expediency of using mass open online courses is beyond question in case students demonstrate a high level of motivation and self-control, and in case they are eager to acquire new knowledge, improve or form all the necessary competencies. In this case, the formation of the individual educational trajectory, the development and self-development of the individual are sure to happen.

One of the well-known Ukrainian MOOC platforms is the OUM which hosts courses for public and civic education. The comparison of this online platform with other Ukrainian MOOC (Prometheus, Edera) showed that they have the same characteristics (the content in Ukrainian, free courses, automatic certificate generation, information on new courses through a digest, etc.).

The OUM platform provides a possibility to form the individual educational trajectory which is displayed in the form of an educational web. Working in one thematic area, the participants of courses can gradually move to another area and take a certain number of courses on another subject. Accordingly, the web will expand in relation to successfully completed online courses.

Most courses on this platform are developed for adult audience; they are based on watching videos and taking test blocks which consist of test assignments.

\section{CONFLICT OF INTEREST}

The authors declare no conflict of interest

\section{AUTHOR CONTRIBUTIONS}

Sergii Sharov developed the structure of the article, wrote and refined the paper. Vira Kolmakova provided support in the analysis and the presentation of the obtained data. Tetiana Sharova took most of the online course on the OUM platform, helping to collect data for analysis. Tetiana Kamyshova organized a review and design of the literature. All authors had approved the final version.

\section{REFERENCES}

[1] M. Sitsinska et al., "Current threats to the sustainable development of Ukraine's higher education system," Universal Journal of Educational Research, vol. 8, no. 11D, pp. 37-46, 2020.

[2] S. Sharov, O. Filatova, and T. Sharova, "The development of an online platform for studying Ukrainian literature," TEM Journal, vol. 9, no. 3 , pp. 1171-1178, 2020.

[3] M. Cacheiro-Gonzalez, A. Medina-Rivilla, M. Dominguez-Garrido, and M. Medina-Dominguez, "The learning platform in distance higher education: Student's perceptions," Turkish Online Journal of Distance Education, vol. 20, no. 1, pp. 71-95, 2019.

[4] B. Akhmetov et al., "Problems of development of a cloud-oriented educational environment of the university," International Journal of Advanced Trends in Computer Science and Engineering, vol. 9, no. 2, pp. 2196-2203, 2020.

[5] I. Prokopenko and S. Berezhna, "Higher education institutions in Ukraine during the coronavirus, or COVID-19, outbreak: New challenges vs new opportunities," Revista Romaneasca pentru Educatie Multidimensionala, vol. 12, no. 1, pp. 130-135, 2020.

[6] V. M. Kukharenko, "Open distance courses," Computer at School and Family, vol. 1, pp. 23-28, 2015. 
[7] M. Berezytskyi and V. Oleksyuk, "Massive open online coursesas a stage in the development of e-learning," Information Technologies and Learning Tools, vol. 56, no. 6, pp. 51-63, 2016.

[8] E. Smyrnova-Trybulska et al., "MOOCs - Theoretical and practical aspects: Comparison of selected research results: Poland, Russia, Ukraine, and Australia," in Proc. International Conferences on ITS, ICEduTech and STE, 2016, pp. 107-114.

[9] H. Shalatska, "The efficiency of MOOCs implementation in teaching English for professional purposes," Information Technologies and Learning Tools, vol. 66, no. 4, pp. 186-196, 2018.

[10] T. A. Vakaliuk et al., "Using massive open online courses in teaching the subject "computer networks" to the future IT specialists," in Proc ICTERI Conf., 2020, pp. 665-676.

[11] T. Oktavia et al., "The comparison of MOOC (massive open online course) platforms of edX and Coursera (study case: Student of programming courses)," in Proc. IEEE International Conference on Information Management and Technology, 2018, pp. 339-344.

[12] S. Sharov, V. Liapunova, and T. Sharova, "Analysis of the opportunities of the prometheus platform for the professional development of future teachers," TEM Journal, vol. 8, no. 4, pp. 1469-1476, 2019.

[13] O. Semenikhina et al., "The open digital educational resources in it-technologies: quantity analysis," Information Technologies and Learning Tools, vol. 75, no. 1, pp. 331-348, 2020.

[14] M. Sedra, and S. Bennani, "Competency based approach: Modeling and implementation," International Journal of Emerging Technologies in Learning, vol. 15, no. 2, pp. 230-238, 2020.

[15] S. Sylkina, "On-lain osvita yak nova praktyka humanizmu," Philosophy of education, vol. 1, no. 18, pp. 117-124, 2016.

[16] B. Yıldırım, "MOOCs in STEM education: Teacher preparation and views," Technology, Knowledge and Learning, pp. 1-26, 2020.

[17] I. Bacurovska, "Pedahohichna klasyfikatsiia masovykh vidkrytykh dystantsiinykh kursiv," Educational discourse, vol. 3, no. 15, pp. 108-120, 2016.

[18] B. Toven-Lindsey, R. Rhoads, and J. Lozano, "Virtually unlimited classrooms: Pedagogical practices in massive open online courses," The Internet and Higher Education, vol. 24, pp. 1-12, 2015.

[19] L. Maksymenko, "Novi tekhnolohii v osviti: masovi vidkryti onlainovi kursy (MVOK)," Postmethodology, vol. 1, pp. 49-52, 2015.

[20] D. Yener, "Students' perceived service quality of distance learning courses in a dual-mode education system," Contemporary Educational Technology, vol. 4, no. 1, pp. 50-65, 2013.

[21] L. Yuan and P. Powell, "MOOCs and open education: Implications for higher education," ELearning Papers, vol. 33, no. 2, pp. 1-7, 2013.

[22] N. Albelbisi, F. D. Yusop, and U. K. M. Salleh, "Mapping the factors influencing success of massive open online courses (MOOC) in higher education," Eurasia Journal of Mathematics, Science and Technology Education, vol. 14, no. 7, pp. 2995-3012, 2018.

[23] R. S. Jansen et al., "Supporting learners' self-regulated learning in Massive Open Online Courses," Computers and Education, vol. 146, 2020.

[24] D. Gamage, I. Perera, and S. Fernando, "Exploring MOOC user behaviors beyond platforms," International Journal of Emerging Technologies in Learning, vol. 15, no. 8, pp. 161-179, 2020.

[25] S. Li, Z. Sun, and L. Luo, "Differences in learning effects among teachers who participate in individual and in groups in a MOOC," International Journal of Information and Education Technology, vol. 11 , no. 4 , pp. 184-188.

Copyright $\odot 2021$ by the authors. This is an open access article distributed under the Creative Commons Attribution License which permits unrestricted use, distribution, and reproduction in any medium, provided the original work is properly cited (CC BY 4.0).

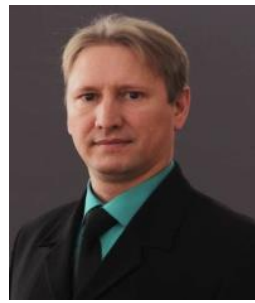

Sergii Sharov is an associate professor of the Department of Computer Sciences in Dmytro Motornyi Tavria State Agrotechnological University. He graduated from Bogdan Khmelnitsky Melitopol State Pedagogical University (master of informatics, teacher of informatics of the higher educational institution) \& the $\mathrm{PhD}$ of pedagogical sciences (theory of teaching). He teaches various subjects including teaching programming, databases, media literacy, history of Ukrainian literature. His research interests include the use of ICT in high school, massive open online courses, social competence of students. Mr. Sharov has been a member of International association for community development in 2020. He is also been a member of public organizations "Innovative horizons of Ukraine" and "Ukrainian Educational Research Association".

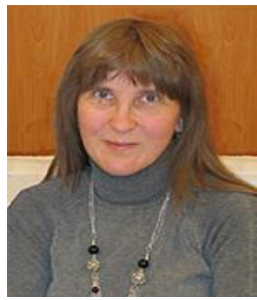

Vira Kolmakova is a senior lecturer of the Department of Computer Science, Information and Communication Technologies, Pavlo Tychyna Uman State Pedagogical University. She graduated from Odesa I. I. Mechnikov National University, specialty Applied Mathematics, specialization Mathematical software. She teaches various subjects, including mathematical logic and algorithm theory, computer architecture and computer systems configuration, and database organization and administration. Research interests - the use of information technology in the teaching of computer science disciplines, inclusion, digital competence of students. Ms. Kolmakova is a member of the Ukrainian Society for Materials Destruction Mechanics. She is also an instructor at the CISCO Network Academy.

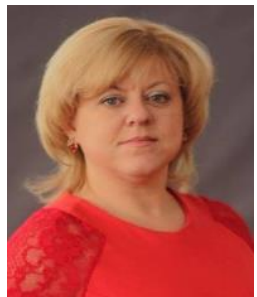

Tetiana Sharova is professor of the Department of Social Sciences and Humanities in Dmytro Motornyi Tavria State Agrotechnological University. She graduated from Bogdan Khmelnitsky Melitopol State Pedagogical University (master in teaching of Ukrainian and Ukrainian literature, master in teaching of German language and world literature,) \& the $\mathrm{PhD}$ of philological sciences (theory of Ukrainian literature). Her academic interest in the field of philology, pedagogy, application of ICT in higher education. Dr. Sharova is been a member of public organizations "Innovative horizons of Ukraine" and "Ukrainian Educational Research Association".

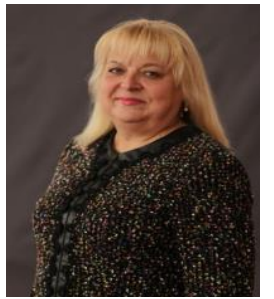

Tetiana Kamyshova is a senior lecturer of the Department of Germanic Philology in Bogdan Khmelnitsky Melitopol State Pedagogical University. She graduated from Zaporizhzhya National University (specialty: English and German) \& the PhD of Philological Sciences (theory of literature). She teachers various subjects including practical course of English, comparative grammar of English and Ukrainian languages, basic translation, theory of translation. Her research interests include genreology, the history of literature, lexicology, stylistics, theory of education, basic translation. 